\title{
The 2"nd Balkan Congress of Nuclear Medicine and the Serbian C'ongress of Nuclear Medicine
}

The $2^{\text {nd }}$ Balkan Congress of Nuclear Medicine was held in Hotel Zira in Belgrade from May $8^{\text {th }}$ to $12^{\text {th }} 2013$, in conjunction with the Serbian Congress of Nuclear Medicine. The Congress was organized by the Serbian Nuclear Medicine Society and the Section of Nuclear Medicine of the Serbian Medical Society, under the auspice of the European Association of Nuclear Medicine and the Ministry of Health of the Republic of Serbia. These events coincided with the $55^{\text {th }}$ anniversary of nuclear medicine in Serbia.

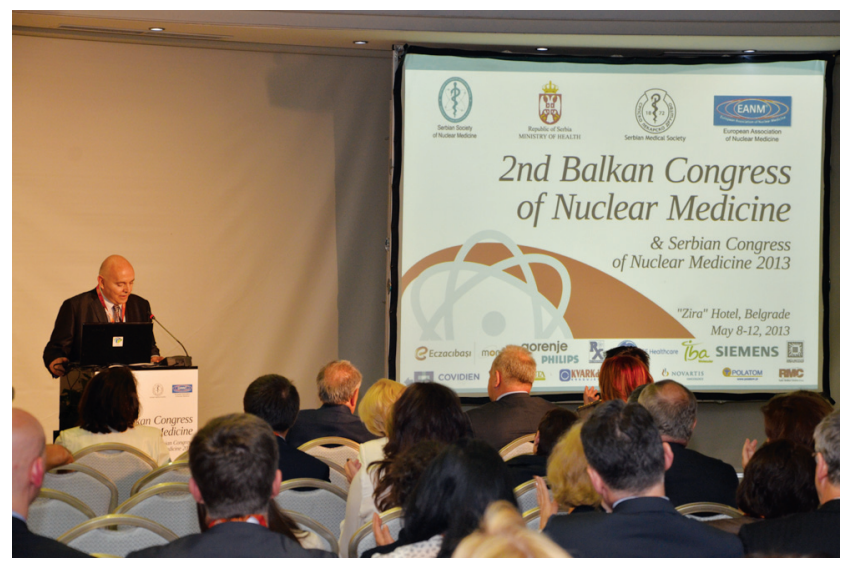

Professor Vladimir Obradovic, President of the $2^{\text {nd }}$ BCNM2013, welcomed participants at the Opening Ceremony

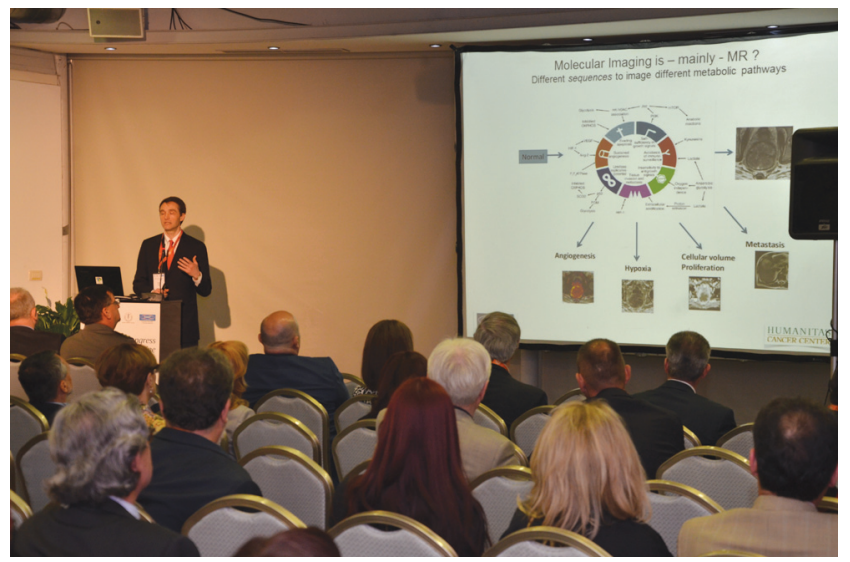

Professor Arturo Chiti, President-Elect of EANM delivered Plenary Lecture
Two hundred and twenty participants attended the Congress from different Balkan countries (Bulgaria, Croatia, FYR of Macedonia, Greece, Romania, Serbia, Slovenia and Turkey), as well as from the Czech Republic, Cyprus, Germany, Iran, Hungary, Poland, Portugal, Tunisia. There were 44 oral and 93 poster presentations.

Twenty-four outstanding invited speakers covered state-of-the-art topics in general nuclear medicine and PET. It was a great honor that the plenary lecture on the future of hybrid imaging was given by Professor Arturo Chiti, the President-Elect of the European Association of Nuclear Medicine. The other two distinguished EANM representatives and invited speakers were Dominique Le Gudulec (France) and Marina Hodolic (Slovenia). The invited speakers from the USA included Naomi Alazraki, Karin Knesaurek, Christopher Palestro, Andrew Taylor and Alan Waxman. Other invited lectures were given by Nermina Beslic (Bosnia and Herzegovina), Maria Garcheva and Elena Piperkova (Bulgaria), Drazen Huic and Ivan Mihaljevic (Croatia), Svetlana Miceva-Ristevska (FYR Macedonia), Andreas Fotopoulos and Maria Koutelou (Greece), Raluca Mititely (Romania), Jasna Mihailovic and Dragana Sobic Saranovic (Serbia), Sergej Hojker (Slovenia), and Seyfettin Iligan, Ozlem Kapucu and Omer Ugur (Turkey). The attendees also enjoyed listening Hans Biersak (Germany) on innovations in PET/CT for malignant melanoma.

The Congress brought together 14 exhibitors well-known in the field of nuclear medicine technology, radiopharmaceuticals and radiation protection. Hotel Zira provided great accommodation and venue for this meeting.

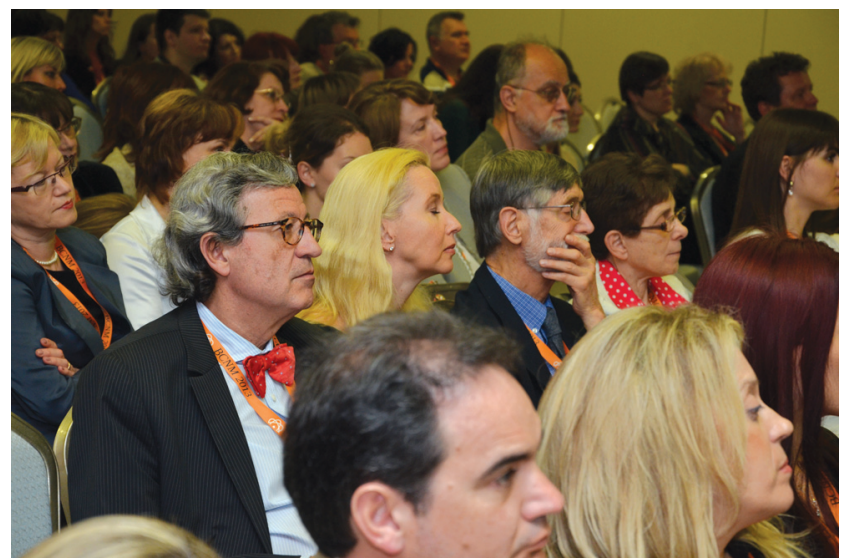

During scientific sessions 
The President of the Congress, Professor Vladimir Obradovic, the Secretary General, Professor Dragana Sobic Saranovic, the President of the Scientific Committee, Professor Vera Artiko, and the entire Organizing Committee did their best to ensure memorable scientific and social events. The highlights include the Opening Ceremony with the charming classical music performed by young artists, pleasant evenings in Skadarlija, the bohemian district in the heart of Belgrade, and gourmet dining in the restaurant on the confluence of Sava and Danube rivers with the breath taking views of the old town. The participants enjoyed opportunities to go sightseeing Belgrade and enjoy its charm and hospitality.

The $2^{\text {nd }}$ Balkan Congress of Nuclear Medicine successfully combined the high-level scientific program and enlightening social interactions, blended with great hospitality. For program details, please visit www.bcnm2013.

Dragana Sobic Saranovic, Vera Artiko 